\title{
URGENSI PERUBAHAN UU NOMOR 5 TAHUN 1999 DALAM RANGKA HARMONISASI HUKUM PERSAINGAN USAHA DI ASEAN
}

\author{
Marta Sri Wahjuni \\ Fakultas Hukum, Universitas Tarumanagara Jakarta \\ Email: MSWahjuni@gmail.com
}

Masuk :13-04-2019, revisi: 13-04-2019, diterima untuk diterbitkan : 09-09-2019

\begin{abstract}
ABSTRAK
Undang-Undang Nomor 5 Tahun 1999 tentang Larangan Praktik Monopoli dan Persaingan Usaha Tidak Sehat ("UU Nomor 5 Tahun 1999") pada prinsipnya diundangkan dengan tujuan untuk menjamin kepastian kesempatan berusaha yang sama bagi setiap pelaku usaha di Indonesia serta dalam rangka mewujudkan iklim usaha yang kondusif melalui pengaturan persaingan usaha yang sehat. Namun demikian UU Nomor 5 Tahun 1999 tampaknya sudah tidak dapat mengakomodir perkembangan dunia persaingan usaha yang semakin mengglobal khususnya di kawasan regional ASEAN dengan lahirnya Asean Economic Community (AEC) pada akhir tahun 2015. Penelitian ini bertujuan untuk menjawab 2 permasalahan: (1) mengapa perubahan terhadap UU Nomor 5 Tahun 1999 perlu segera dilakukan? dan (2) apakah Rancangan Undang-Undang Larangan Praktik Monopoli dan Persaingan Usaha Tidak Sehat ("RUU") perlu disesuaikan dengan The ASEAN Regional Guidelines on Competition Policy 2010? Untuk menjawab permasalahan dalam penelitian ini, peneliti menggunakan metode penelitian hukum normatif. Berdasarkan hasil penelitian diketahui bahwa perubahan terhadap UU Nomor 5 Tahun 1999 perlu segera dilakukan. Selain itu, RUU perlu disesuaikan dengan The ASEAN Regional Guidelines on Competition Policy 2010 karena meskipun saat ini masih berbentuk soft law dan belum mempunyai kekuatan mengikat bagi negara-negara anggota ASEAN tetapi Regional Guidelines merupakan langkah awal atau titik tolak menuju harmonisasi hukum persaingan usaha di wilayah regional ASEAN dan roadmap menuju harmonisasi kebijakan persaingan usaha dan undang-undang persaingan usaha di wilayah regional ASEAN telah ditetapkan dengan jelas dalam The ASEAN Competition Action Plan 2025.
\end{abstract}

Kata kunci: persaingan usaha, regional guidelines, harmonisasi

\section{ABSTRACT}

Constitution of 1999 No. 5 concerning Prohibition of Monopolistic Practices and Unfair Business Competition in principle was enacted with the goal of ensuring the certainty of equal business opportunities for every business actor in Indonesia and to create a conducive business climate through the regulation of fair business competition. However, Constitution of 1999 No. 5 seems unable to accommodate the development of an increasingly globalized business competition, especially in the ASEAN region with the appearance of the Asean Economic Community (AEC) at the end of 2015. This study aims to address 2 issues: (1) the reason why Constitution of 1999 No. 5 needs to be revised and (2) whether or not the Bill of Prohibition of Monopolistic Practices and Unfair Business Competition ("Draft Law") be adjusted to the 2010 ASEAN Regional Guidelines on Competition Policy. To answer the questions in this study, the researcher used normative legal research method. Based on the result of the study, changes to Constitution of 1999 No. 5 needs to be done immediately. In addition, the aforementioned Bill needs to be adjusted to the 2010 ASEAN Regional Guidelines on Competition Policy because although being in the form of soft law and without any binding power for countries that are ASEAN members, the Regional Guidelines is the first step, a starting point towards harmonizing business competition law in the ASEAN region, and the roadmap towards harmonizing business competition policies and business competition laws in the ASEAN region are clearly defined in the 2025 ASEAN Competition Action Plan.

Keywords: business competition, regional guidelines, hamonization 


\section{PENDAHULUAN}

\section{Latar Belakang}

Untuk menjamin kepastian kesempatan berusaha yang sama bagi setiap pelaku usaha di Indonesia serta dalam rangka mewujudkan iklim usaha yang kondusif melalui pengaturan persaingan usaha yang sehat, maka pemerintah mengeluarkan Undang-Undang Nomor 5 Tahun 1999 tentang Larangan Praktik Monopoli dan Persaingan Usaha Tidak Sehat ("UU Nomor 5 Tahun 1999"). Pada pokoknya UU Nomor 5 Tahun 1999 mengatur 2 hal, yaitu perjanjian yang dilarang dan kegiatan yang dilarang. Perjanjian yang dilarang berdasarkan UU Nomor 5 Tahun 1999, antara lain adalah perjanjian Oligopoli, Penetapan Harga, Pemboikotan, Kartel, Trust, Oligopsoni, Integrasi Vertikal, Perjanjian Tertutup, dan Perjanjian dengan Pihak Luar Negeri, sedangkan kegiatan yang dilarang berdasarkan UU Nomor 5 Tahun 1999 antara lain adalah Monopoli, Monopsoni, Penguasaan Pasar, dan Persekongkolan. Seiring dengan berjalannya waktu terutama dalam menghadapi era globalisasi di mana lalu lintas perdagangan antar negara semakin bersifat borderless, maka DPR telah menyusun Rancangan Undang-Undang Larangan Praktik Monopoli dan Persaingan Usaha Tidak Sehat (RUU) yang telah resmi disetujui menjadi Rancangan UndangUndang usul inisiatif Dewan Perwakilan Rakyat pada tanggal 28 Mei 2017 untuk mengamandemen UU Nomor 5 Tahun 1999. Namun hingga saat ini RUU ini belum disahkan.

Pengesahan RUU tersebut di atas memiliki arti penting karena dengan lahirnya Asean Economic Community (AEC) pada akhir tahun 2015, berarti lahir pula satu pasar regional yang baru, yaitu pasar regional ASEAN. Para pelaku usaha kini dapat menjalankan bisnis atau usahanya lintas batas negara dengan lebih leluasa. Persaingan usaha akan semakin berat dan kompetitif, sehingga tidak menutup kemungkinan akan terjadi perjanjian-perjanjian kerja sama antara pelaku usaha dari beberapa negara anggota ASEAN. Berbagai upaya yang berkaitan dengan Kebijakan Persaingan Usaha (Competition Policy) di kawasan ASEAN, antara lain tampak dari kesepakatan negaranegara anggota ASEAN untuk membentuk The ASEAN Consultative Forum on Competition dalam forum The $1^{\text {st }}$ ASEAN Conference on Fair Competition Law and Policy pada bulan Maret 2003 (Pardede, 2010). Upaya lain dalam rangka mewujudkan kebijakan persaingan usaha di kawasan ASEAN adalah dengan dibentuknya ASEAN Experts Group on Competition (AEGC) pada tahun 2007, sebagai forum regional untuk diskusi dan kerjasama dalam Hukum dan Kebijakan Persaingan (Juwarno, 2011). Pada bulan Agustus 2010, AEGC menerbitkan The ASEAN Regional Guidelines on Competition Policy 2010 (Regional Guidelines). Keberadaan Regional Guidelines tersebut mempunyai arti penting bagi negara-negara anggota ASEAN, karena dengan dikeluarkannya Regional Guidelines, negara-negara anggota ASEAN mempunyai referensi yang dapat dijadikan pegangan dalam usaha meningkatkan kesadaran masyarakat ASEAN dalam menciptakan lingkungan persaingan usaha yang sehat. Tanpa adanya persaingan usaha yang sehat, maka akan menyebabkan adanya harga yang tinggi serta pembatasan output dan kolusi antar pelaku usaha (Yosefa, 2010). Selain itu, keberadaan Regional Guidelines juga diharapkan dapat membantu mewujudkan kawasan ekonomi $A S E A N$ yang berdaya saing tinggi dan sebagai langkah awal menuju harmonisasi hukum persaingan usaha di kawasan regional ASEAN.

\section{Rumusan Masalah}

1. Mengapa perubahan terhadap Undang-Undang Nomor 5 Tahun 1999 tentang Larangan Praktik Monopoli dan Persaingan Usaha Tidak Sehat perlu segera dilakukan?

2. Apakah Rancangan Undang-Undang Larangan Praktik Monopoli dan Persaingan Usaha Tidak Sehat perlu disesuaikan dengan The ASEAN Regional Guidelines on Competition Policy 2010 ? 


\section{METODE PENELITIAN}

Sesuai dengan pokok-pokok permasalahan yang diteliti, maka cara atau metode yang digunakan dalam penelitian hukum ini adalah metode penelitian hukum normatif. Penelitian hukum normatif disebut juga penelitian hukum doktrinal yang terdapat dalam peraturan perundang-undangan atau hukum sebagai kaidah atau norma yang merupakan patokan berperilaku manusia yang dianggap pantas (Amiruddin dan Asikin, 2003). Dalam penelitian ini, yang diteliti adalah sejauh mana hukum positif tertulis yang ada itu sinkron atau serasi satu dengan yang lainnya (Sinamo, 2009). Jenis data yang digunakan dalam penelitian ini adalah data sekunder yang bersifat kualitatif. Penelitian yuridis normatif yang bersifat kualitatif adalah penelitian yang mengacu pada norma hukum yang terdapat dalam peraturan perundang-undangan dan putusan pengadilan serta norma-norma yang hidup dan berkembang dalam masyarakat (Ali, 2009).

\section{HASIL PENELITIAN DAN PEMBAHASAN Urgensi perubahan terhadap Undang-Undang Nomor 5 Tahun 1999 tentang Larangan Praktik Monopoli dan Persaingan Usaha Tidak Sehat}

Landasan filosofis dari penyusunan UU Nomor 5 Tahun 1999 adalah Pancasila dan UndangUndang Dasar 1945 serta berdasarkan kepada demokrasi ekonomi dengan memperhatikan keseimbangan antara kepentingan pelaku usaha dan kepentingan umum dengan tujuan untuk: menjaga kepentingan umum dan melindungi konsumen; menumbuhkan iklim usaha yang kondusif melalui terciptanya persaingan usaha yang sehat dan menjamin kepastian kesempatan berusaha yang sama bagi setiap orang; mencegah praktik-praktik monopoli dan atau persaingan usaha tidak sehat yang ditimbulkan pelaku usaha; serta menciptakan efektivitas dan efisiensi ekonomi nasional sebagai salah satu upaya meningkatkan kesejahteraan rakyat Indonesia (Margono, 2009). UU Nomor 5 Tahun 1999 kini telah berusia 20 tahun, oleh karena itu perlu dicermati kembali apakah ketentuan-ketentuan dalam UU Nomor 5 Tahun 1999 masih relevan dan dapat mengakomodir kebutuhan serta perkembangan yang terjadi dalam masyarakat. Dalam penelitian ini, peneliti membatasi ruang lingkup penelitian ini hanya mengenai pendefinisian pelaku usaha dalam UU Nomor 5 Tahun 1999, kewenangan Komisi Pengawas Persaingan Usaha (KPPU) dan program leniensi.

Berdasarkan ketentuan Pasal 1 UU Nomor 5 Tahun 1999, yang dimaksud dengan pelaku usaha adalah: "Setiap orang perorangan atau badan usaha, baik yang berbentuk badan hukum atau bukan badan hukum yang didirikan dan berkedudukan atau melakukan kegiatan dalam wilayah hukum negara Republik Indonesia, baik sendiri maupun bersama-sama melalui perjanjian, menyelenggarakan berbagai kegiatan usaha dalam bidang ekonomi." Pendefinisian pelaku usaha berdasarkan ketentuan Pasal 1 UU Nomor 5 Tahun 1999 tersebut sangat sempit karena pelaku usaha hanya berarti pelaku usaha Indonesia saja, sehingga jika terjadi pelanggaran terhadap UU Nomor 5 Tahun 1999 yang dilakukan oleh pelaku usaha di luar pelaku usaha Indonesia, maka UU Nomor 5 Tahun 1999 tidak dapat diberlakukan. Sebagai contohnya pada akhir tahun 2016, terjadi dugaan adanya cross border cartel berawal ketika para pengusaha mengeluhkan tarif pengangkutan peti kemas dari Batam ke Singapura yang lebih mahal daripada pengangkutan dari Jakarta ke Singapura atau bahkan dari Singapura ke Malaysia. Biaya angkutan untuk kontainer ukuran 20 feet dari Batam ke Singapura mencapai USD 555, sedangkan ukuran 40 feet mencapai USD 750, padahal jarak Batam dengan Singapura hanya 28 kilometer yang bisa ditempuh dengan angkutan kontainer dalam 2 jam. Biaya ini sangat mahal jika dibandingkan dengan biaya angkut kontainer dari Singapura ke Malaysia yang jaraknya lebih jauh yakni 374 kilometer yang membutuhkan waktu tempuh 20 jam, untuk kontainer 20 feet hanya USD 122 dan 40 feet hanya USD 277 (Batam Pos, 2018). Menanggapi keluhan tersebut, KPPU Kantor Perwakilan Daerah Batam mengambil langkah untuk melakukan penyelidikan. Namun demikian, ternyata KPPU tidak 
dapat langsung memeriksa perusahaan peti kemas karena perusahaan tersebut bukan pelaku usaha Indonesia tetapi perusahaan yang berbasis di Singapura, perusahaan yang ada di Batam hanya bersifat sebagai agen saja. Dugaan cross border cartel di Batam hanya salah satu contoh saja, bukan tidak mungkin akan terjadi pelanggaran-pelanggaran yang lain yang melibatkan pelaku usaha asing di masa yang akan datang. Investigasi terhadap pelanggaran-pelanggaran yang dilakukan oleh pelaku usaha asing tidak dapat dilakukan oleh KPPU karena pendefinisian Pasal 1 UU Nomor 5 Tahun 1999 yang sangat sempit sehingga tidak memungkinkan KPPU untuk membidik pelaku usaha asing yang melakukan pelanggaran di bidang persaingan usaha di wilayah Republik Indonesia.

Pendefinisian Pasal 1 UU Nomor 5 Tahun 1999 di atas berkaitan erat dengan kewenangan KPPU. Untuk mengawasi pelaksanaan UU Nomor 5 Tahun 1999, maka pada tanggal 8 Juli 1999 telah dibentuk KPPU sebagai Lembaga Pengawas Independen berdasarkan Keputusan Presiden Nomor 75 Tahun 1999 tentang Komisi Pengawas Persaingan Usaha. Sebagai lembaga yang independen, KPPU dalam menjalankan tugas dan wewenangnya terlepas dari pengaruh serta kekuasaan pemerintah serta pihak-pihak manapun, oleh karena itu KPPU bertanggung jawab kepada Presiden selaku kepala eksekutif. Anggota KPPU diangkat dan diberhentikan oleh Presiden dengan persetujuan Dewan Perwakilan Rakyat dengan masa jabatan 5 tahun dan dapat diangkat kembali untuk 1 kali masa jabatan berikutnya. KPPU terdiri atas seorang Ketua yang merangkap anggota, seorang Wakil Ketua yang merangkap anggota dan sekurang-kurangnya 7 anggota. Berdasarkan ketentuan Pasal 36 UU Nomor 5 Tahun 1999, kewenangan KPPU meliputi:

a. menerima laporan dari masyarakat dan atau dari pelaku usaha tentang dugaan terjadinya praktek monopoli dan atau persaingan usaha tidak sehat;

b. melakukan penelitian tentang dugaan adanya kegiatan usaha dan atau tindakan pelaku usaha yang dapat mengakibatkan terjadinya praktek monopoli dan atau persaingan usaha tidak sehat;

c. melakukan penyelidikan dan atau pemeriksaan terhadap kasus dugaan praktek monopoli dan atau persaingan usaha tidak sehat yang dilaporkan oleh masyarakat atau oleh pelaku usaha atau yang ditemukan oleh Komisi sebagai hasil penelitiannya;

d. menyimpulkan hasil penyelidikan dan atau pemeriksaan tentang ada atau tidak adanya praktek monopoli dan atau persaingan usaha tidak sehat;

e. memanggil pelaku usaha yang diduga telah melakukan pelanggaran terhadap ketentuan undangundang ini;

f. memanggil dan menghadirkan saksi, saksi ahli, dan setiap orang yang dianggap mengetahui pelanggaran terhadap ketentuan undang-undang ini;

g. meminta bantuan penyidik untuk menghadirkan pelaku usaha, saksi, saksiahli, atau setiap orang sebagaimana dimaksud huruf e dan huruf $\mathrm{f}$, yang tidak bersedia memenuhi panggilan Komisi;

h. meminta keterangan dari instansi Pemerintah dalam kaitannya dengan penyelidikan dan atau pemeriksaan terhadap pelaku usaha yang melanggar ketentuan undang-undang ini;

i. mendapatkan, meneliti, dan atau menilai surat, dokumen, atau alat bukti lain guna penyelidikan dan atau pemeriksaan;

j. memutuskan dan menetapkan ada atau tidak adanya kerugian di pihak pelaku usaha lain atau masyarakat;

k. memberitahukan putusan Komisi kepada pelaku usaha yang diduga melakukan praktek monopoli dan atau persaingan usaha tidak sehat;

1. menjatuhkan sanksi berupa tindakan administratif kepada pelaku usaha yang melanggar ketentuan undang-undang ini. 
Ruang lingkup kewenangan yang diberikan kepada KPPU berdasarkan UU Nomor 5 Tahun 1999 sebagaimana tersebut di atas berkaitan erat dengan ketentuan Pasal 1 Undang-Undang Nomor 5 Tahun 1999 tentang definisi pelaku usaha. KPPU hanya dapat melakukan penelitian dan penyelidikan terhadap pelaku usaha Indonesia sesuai dengan ketentuan Pasal 1 Undang-Undang Nomor 5 Tahun 1999. Pendefinisian Pasal 1 UU Nomor 5 Tahun 1999 yang sempit tersebut tentunya juga akan membawa akibat terhadap keterbatasan kewenangan KPPU jika terjadi pelanggaran-pelanggaran yang melibatkan grup perusahaan yang memiliki Parent Company/ Holding Company di luar wilayah Indonesia. Berdasarkan definisi Pasal 1 UU Nomor 5 Tahun 1999, jika terjadi pelanggaran oleh anak perusahaan di Indonesia yang dikendalikan oleh Parent Company/Holding Company di luar wilayah Indonesia, maka KPPU hanya memiliki kewenangan untuk melakukan penyelidikan terhadap anak perusahaan yang ada di Indonesia saja. Singkatnya, untuk saat ini KPPU tidak dapat menangani pelanggaran-pelanggaran yang melibatkan pelaku usaha asing. Jika dibiarkan maka pada akhirnya akan merugikan pelaku usaha dan konsumen di Indonesia.

Selain masalah pendefinisian pelaku usaha yang sempit dan keterbatasan kewenangan KPPU dalam menangani pelanggaran-pelanggaran yang melibatkan pelaku usaha asing sebagaimana telah diuraikan di atas, maka urgensi perubahan terhadap UU Nomor 5 Tahun 1999 adalah mengenai program leniensi sebagai salah satu cara alternatif untuk mengungkap serta menangani perkara kartel maupun cross border cartel yang belum ada pengaturannya dalam UU Nomor 5 Tahun 1999. Program leniensi merupakan pengampunan atau keringanan hukuman yang diberikan kepada pelaku kartel jika mengakui dan/atau membantu mengungkapkan pihakpihak yang berkolusi melakukan kartel (Anggraini, 2011). Program leniensi ini biasanya diberikan dalam hal otoritas persaingan usaha atau badan penegak hukum lainnya tidak mengetahui adanya kartel maupun dalam hal otoritas persaingan usaha atau badan penegak hukum lainnya mengetahui kartel tetapi tidak memiliki bukti yang cukup untuk melanjutkan penyelidikan atau mengadili. Berkaitan dengan program leniensi ini, $A E G C$ juga telah merumuskan rambu-rambu atau panduan bagi negara-negara anggota ASEAN yang dituangkan dalam section 6.9 Regional Guidelines:

6.9.1 AMSs may introduce a leniency programme targeted at undertakings who have participated in cartel activities and therefore are liable for infringing the prohibition against anticompetitive agreements, but who would nevertheless like to come clean and provide the competition regulatory body or other law enforcement body with evidence of cartel.

6.9.2 These undertakings may be deterred from come forward and "blowing the whistle" for fear that they may expose themselves to hefty financial penalties for their own involvement in cartel.

6.9.3 Due to the secret nature of cartels, undertakings participating or who have participated in them may be given an incentive to come forward and report on cartel's activities (ASEAN Regional Guidelines on Competition Policy, 2010).

Melalui section 6.9 The ASEAN Regional Guidelines on Competition Policy 2010 tersebut di atas, negara-negara anggota ASEAN diharapkan dapat memperkenalkan leniency programme sebagai alternatif dalam mengungkap dan menangani perkara kartel dan dengan memberikan kesempatan bagi pelaku usaha yang terlibat dalam kartel untuk menjadi "whistle blower". Pengaturan mengenai program leniensi ini sudah diakomodir dalam RUU yang baru, sehingga di masa yang akan datang jika RUU ini disahkan maka diharapkan KPPU dapat menangani perkaraperkara kartel dengan lebih mudah karena sebagai "whistle blower” tentunya pelaku usaha lebih 
bersikap kooperatif dan dengan demikian perkara-perkara kartel dapat ditangani dengan lebih cepat dan efisien.

\section{Urgensi penyesuaian Rancangan Undang-Undang Larangan Praktik Monopoli dan Persaingan Usaha Tidak Sehat dengan The ASEAN Regional Guidelines on Competition Policy 2010 dalam rangka harmonisasi hukum persaingan usaha di $A S E A N$}

UU Nomor 5 Tahun 1999 diundangkan dan diberlakukan jauh sebelum dikeluarkannya Regional Guidelines oleh $A E G C$, oleh karena itu dapat dipahami jika terdapat perbedaanperbedaan dalam pengaturannya. Pencanangan The ASEAN Competition Action Plan (ACAP) 2025 menuju harmonisasi hukum persaingan usaha di wilayah regional ASEAN merupakan alasan utama untuk melakukan penyesuaian RUU yang baru dengan Regional Guidelines.

The

ASEAN Competition Action Plan (ACAP) 2025 merinci tujuan strategis, inisiatif-inisiatif yang akan dilakukan dan hasil-hasil yang diharapkan dapat dicapai berkaitan dengan kebijakan persaingan usaha dan undang-undang persaingan usaha di ASEAN selama 10 tahun (2016-2025). ACAP 2025 disusun berdasarkan pada langkah-langkah strategis yang telah dicanangkan melalui terbentuknya Masyarakat Ekonomi ASEAN yang dituangkan dalam ASEAN Blueprint 2025. ACAP 2025 berisi lima sasaran strategis yaitu:

a. terbentuknya rezim persaingan usaha yang efektif di semua negara anggota ASEAN;

b. kapasitas lembaga-lembaga persaingan usaha di negara anggota $A S E A N$ diperkuat sehingga dapat menerapkan kebijakan persaingan usaha dan undang-undang persaingan usaha secara efektif;

c. melakukan kerja sama regional berkaitan dengan kebijakan persaingan usaha dan undangundang persaingan usaha;

d. mengembangkan wilayah regional ASEAN sebagai suatu wilayah regional yang sadar persaingan; dan

e. bergerak menuju harmonisasi kebijakan persaingan usaha dan undang-undang persaingan usaha di ASEAN yang lebih luas (greater harmonization) (ASEAN, 2018).

Kelima sasaran strategis di atas dirancang untuk memungkinkan ASEAN mewujudkan visi menyeluruh dari ASEAN yang kompetitif, inovatif, dan dinamis dengan kebijakan dan undangundang persaingan usaha yang efektif dan dapat dilaksanakan. Penelitian ini fokus pada sasaran strategis yang kelima yaitu bergerak menuju harmonisasi yang lebih besar dalam kebijakan persaingan usaha dan undang-undang persaingan usaha di wilayah regional ASEAN. Harmonisasi regional dari kebijakan persaingan usaha dan undang-undang persaingan usaha adalah satu langkah lebih jauh, setelah ASEAN berhasil memperkenalkan legislasi nasional di masing-masing negara anggota yang merupakan sasaran strategis pertama dan secara efektif menegakkan peraturan-peraturan tersebut yang merupakan sasaran strategis kedua. Hal ini berarti, meskipun satu peraturan tidak mungkin cocok untuk semua negara anggota ASEAN dan perbedaanperbedaan mungkin saja terus ada dengan berbagai alasan yang sah, ASEAN juga berkomitmen untuk meningkatkan persamaan-persamaan dan konvergensi dan menghilangkan kontradiksi.

Bagi komunitas hukum internasional, harmonisasi hukum telah menjadi aspirasi sejak jatuhnya Kekaisaran Romawi, yang pada prinsipnya dimaksudkan untuk memenuhi kebutuhan praktik dalam masyarakat (Edward Elgar, 2011). Proses globalisasi dewasa ini juga telah membawa pelaku usaha semakin dekat dalam berinteraksi satu dengan yang lainnya sehingga hal ini juga semakin mendorong kebutuhan akan adanya harmonisasi hukum. Jadi dapat dikatakan bahwa kebutuhan akan adanya harmonisasi hukum merupakan respons masyarakat internasional terhadap globalisasi. Secara umum istilah harmonisasi dapat diartikan sebagai peniadaan atau penghapusan perbedaan-perbedaan yang ada di antara rezim-rezim hukum yang berlaku. Untuk 
menggambarkan proses "harmonisasi hukum" dalam literatur hukum persaingan usaha dikenal berbagai macam istilah, ada yang menggunakan istilah "harmonisasi", "unifikasi", "konvergensi" dan "internasionalisasi". Taylor sebagaimana dikutip oleh Edward Elgar dalam bukunya "Theory and Practice of Harmonisation" membedakan istilah harmonisasi hukum menjadi 2, yaitu "full harmonisation" yaitu di mana 2 atau lebih negara telah menunjukkan $80 \%$ keseragaman dalam substansi dan prosedur undang-undang persaingan usaha mereka, sedangkan "partial harmonisation" adalah suatu kondisi di mana 2 atau lebih negara telah menunjukkan antara 60\%$80 \%$ keseragaman dalam substansi dan prosedur undang-undang persaingan usaha mereka (Edward Elgar, 2011). Sedangkan istilah "konvergensi" mengacu pada suatu keadaan di mana 2 atau lebih negara mencapai tingkat kesamaan yang wajar dalam undang-undang persaingan usaha nasional mereka tetapi tetap mempertahankan standar dan pendekatan yang berbeda. Harmonisasi menurut Taylor mengacu pada proses negosiasi dan kesepakatan tentang standar substantif yang sama yang bersifat mengikat dan dapat diterima oleh berbagai negara dengan budaya persaingan usaha yang berbeda yang mempunyai tahap perkembangan ekonomi yang berbeda dan memiliki tingkat ekonomi yang berbeda satu dengan yang lainnya. Berdasarkan teori harmonisasi dari Taylor sebagaimana diuraikan di atas, maka dapat disimpulkan bahwa upaya yang dilakukan oleh $A E G C$ dalam rangka mewujudkan harmonisasi hukum persaingan usaha di wilayah regional $A S E A N$ saat ini masih dalam keadaan atau tingkat "konvergensi" di mana 10 negara anggota ASEAN masing-masing telah memiliki undang-undang persaingan usaha namun belum semua menerapkannya (Kamboja) dan secara umum pengaturan undang-undang persaingan usaha di tiaptiap negara anggota $A S E A N$ telah mencapai tahapan yang berbeda-beda sesuai dengan kondisi masing-masing negara. Oleh karena itu, dapat dikatakan keberadaaan Regional Guidelines saat ini mempunyai peranan penting bagi proses harmonisasi hukum persaingan usaha di wilayah regional ASEAN. Harmonisasi kebijakan persaingan usaha dan undang-undang persaingan usaha yang lebih besar di $A S E A N$ diharapkan dapat menciptakan lingkungan kebijakan persaingan usaha untuk barang, jasa dan modal untuk bergerak bebas dan tanpa hambatan, sementara perusahaanperusahaan dapat mengoperasikan dan mengalokasikan sumber daya secara seefisien mungkin.

Roadmap menuju harmonisasi kebijakan persaingan usaha dan undang-undang persaingan usaha di wilayah regional ASEAN telah ditetapkan dengan jelas melalui kelima sasaran strategis yang telah dipaparkan di atas dan khususnya berkaitan erat dengan penelitian ini adalah sasaran strategis kelima, di mana persamaan-persamaan dan perbedaan-perbedaaan di semua undang-undang persaingan nasional di masing-masing negara anggota ASEAN akan terus diidentifikasi sehingga diharapkan kesenjangan yang ada akan semakin mengecil beberapa tahun ke depan. Regional Guidelines juga akan direvisi dan revisi tersebut akan dibarengi dengan penandatanganan joint statement oleh Asean Ecomomic Ministers (AEM), di mana hal ini menunjukkan bahwa kekuatan mengikat dari Regional Guidelines akan semakin ditingkatkan. Regional Guidelines meskipun saat ini masih berbentuk soft law dan belum mempunyai kekuatan mengikat bagi negara-negara anggota $A S E A N$ tetapi merupakan langkah awal atau titik tolak menuju harmonisasi hukum persaingan usaha di wilayah regional ASEAN.

\section{KESIMPULAN DAN SARAN}

\section{Kesimpulan}

Berdasarkan hasil penelitian dan pembahasan yang telah diuraikan di atas, maka dapat disimpulkan bahwa:

1. Perubahan terhadap Undang-Undang Nomor 5 Tahun 1999 tentang Larangan Praktik Monopoli dan Persaingan Usaha Tidak Sehat perlu segera dilakukan antara lain oleh karena:

a. pendefinisian pelaku usaha berdasarkan ketentuan Pasal 1 UU Nomor 5 Tahun 1999 sangat sempit karena pelaku usaha hanya berarti pelaku usaha Indonesia saja, sehingga jika terjadi 
pelanggaran terhadap UU Nomor 5 Tahun 1999 yang dilakukan oleh pelaku usaha di luar pelaku usaha Indonesia atau pelaku usaha asing, maka UU Nomor 5 Tahun 1999 tidak dapat diberlakukan;

b. kewenangan KKPU yang diberikan oleh UU Nomor 5 Tahun 1999 sangat terbatas sehingga KPPU tidak dapat menangani pelanggaran-pelanggaran yang melibatkan pelaku usaha asing, berdasarkan ketentuan Pasal 36 UU Nomor 5 Tahun 1999 saat ini KPPU hanya memiliki kewenangan untuk melakukan penyelidikan terhadap pelaku usaha Indonesia saja; dan

c. belum adanya pengaturan mengenai program leniensi sebagai salah satu cara alternatif untuk mengungkap serta menangani perkara kartel maupun cross border cartel dalam UU Nomor 5 Tahun 1999.

2. Rancangan Undang-Undang Larangan Praktik Monopoli dan Persaingan Usaha Tidak Sehat perlu disesuaikan dengan The ASEAN Regional Guidelines on Competition Policy 2010 karena: a. berdasarkan The ASEAN Competition Action Plan (ACAP) 2025, negara-negara anggota $A S E A N$ melalui $A E G C$ telah sepakat untuk mengembangkan wilayah regional ASEAN sebagai suatu wilayah regional yang sadar akan persaingan usaha yang sehat dan terus bergerak menuju harmonisasi kebijakan persaingan usaha dan undang-undang persaingan usaha di ASEAN yang lebih luas (greater harmonization). Regional Guidelines meskipun saat ini masih berbentuk soft law dan belum mempunyai kekuatan mengikat bagi negaranegara anggota $A S E A N$ tetapi merupakan langkah awal atau titik tolak menuju harmonisasi hukum persaingan usaha di wilayah regional ASEAN;

b. Roadmap menuju harmonisasi kebijakan persaingan usaha dan undang-undang persaingan usaha di wilayah regional ASEAN telah ditetapkan dengan jelas melalui kelima sasaran strategis yang telah dipaparkan di atas dan khususnya berkaitan erat dengan penelitian ini adalah sasaran strategis kelima, di mana persamaan-persamaan dan perbedaan-perbedaaan di semua undang-undang persaingan nasional di masing-masing negara anggota ASEAN akan terus diidentifikasi sehingga diharapkan kesenjangan yang ada akan semakin mengecil beberapa tahun ke depan. Regional Guidelines juga akan ditinjau secara berkala serta direvisi dan revisi tersebut akan dibarengi dengan penandatanganan joint statement oleh AEM, di mana hal ini menunjukkan bahwa kekuatan mengikat dari Regional Guidelines akan semakin ditingkatkan.

\section{Saran}

Berdasarkan hasil penelitian, pembahasan dan kesimpulan di atas, peneliti memberikan saransaran sebagai berikut:

1. Pemerintah Republik Indonesia segera melakukan amandemen terhadap UU Nomor 5 Tahun 1999 tentang Larangan Praktik Monopoli dan Persaingan Usaha Tidak Sehat dan menyempurnakan RUU tentang Perubahan atas UU Nomor 5 Tahun 1999 tentang Larangan Praktik Monopoli dan Persaingan Usaha Tidak Sehat sesuai dengan The ASEAN Regional Guidelines on Competition Policy 2010;

2. KPPU sebagai garda terdepan dalam pelaksanaan penegakan hukum persaingan usaha di Indonesia sebaiknya diberikan kewenangan yang lebih luas sehingga tidak hanya dapat menangani pelanggaran-pelanggaran yang dilakukan oleh pelaku usaha Indonesia saja, tetapi juga dapat membidik pelaku usaha asing yang melakukan pelanggaran-pelanggaran terhadap hukum persaingan usaha yang berlaku di Indonesia yang berpotensi terjadi dengan terbentuknya Asean Economic Community pada akhir tahun 2015; dan 
3. Sebaiknya pemerintah Republik Indonesia juga mempertimbangkan dan menyetujui program leniensi (leniency programme) sebagai salah satu cara alternatif untuk mengungkap serta menangani perkara kartel maupun cross border cartel sebagaimana yang diatur dalam The ASEAN Regional Guidelines on Competition Policy 2010 yang merupakan salah satu perubahan yang cukup signifikan yang dimuat dalam RUU tentang Perubahan atas UU Nomor 5 Tahun 1999 tentang Larangan Praktik Monopoli dan Persaingan Usaha Tidak Sehat

\section{Ucapan Terima Kasih}

Penelitian ini tidaklah mungkin dapat diselesaikan dengan baik tanpa bantuan dan motivasi yang diberikan oleh berbagai pihak, baik secara langsung maupun tidak langsung. Pada kesempatan ini, peneliti mengucapkan terima kasih yang sebesar-besarnya kepada:

1. Yang terhormat Prof. M. Hawin, S.H., LL.M., Ph.D, seorang guru besar yang bijaksana dan sangat sabar, yang telah berkenan menyediakan waktu untuk peneliti, memberikan dorongan semangat, arahan-arahan serta koreksi-koreksinya, sehingga peneliti dapat menyelesaikan penelitian ini dengan baik; dan

2. Yang terhormat Prof. Dr. Sigit Riyanto, S.H., LL.M., seorang guru besar yang luar biasa dan sangat kompeten di bidangnya, yang telah berkenan untuk memberikan arahan-arahan yang konstruktif, sehingga peneliti dapat menyelesaikan penelitian ini dengan baik.

\section{REFERENSI}

Ali, Z. (2009). Metode penelitian hukum. Jakarta: Sinar Grafika.

Amiruddin \& Asikin, Z. (2003). Pengantar metode penelitian hukum. Jakarta: PT RajaGrafindo Persada.

Anggraini, A.M.T. (2011). Program leniency dalam mengungkap kartel menurut hukum persaingan usaha. Jurnal Persaingan Usaha (Edisi ke-6). hlm. 103.

ASEAN. (2010). Regional guidelines on competition policy. Diunduh dari http://www.asean.org/ storage/images/ 2012/ publications IASEAN \% 20 Regional $\% 20$ Guidelines\%20on\%20Competition\%20Policy.pdf.

ASEAN. (2012). Sectoral bodies under the purview of AEM. Diunduh dari http://asean.org/aseaneconomic-community/sectoral-bodies-under-the-purview-of-aem/competitionpolicy/overview/.

Batam Pos. (2018, November 1). KPPU tak berdaya usut kasus kartel tarif peti kemas di Batam. Batam Pos. Diunduh dari https: //batampos.co.id/

Elgar, E. (2011). Theory and practice of harmonisation. UK: Cheltenham.

Juwarno, T. (2011). Menuju otoritas persaingan usaha ASEAN. Majalah Kompetisi, 30, 3.

Margono, S. (2009). Hukum antimonopoli. Jakarta: Sinar Grafika.

Pardede, S.M. (2010). Persaingan sehat \& akselerasi pembangunan ekonomi. Jakarta: Pustaka Sinar Harapan.

Republik Indonesia. (1999). Undang-Undang Nomor 5 Tahun 1999 tentang Larangan Praktik Monopoli dan Persaingan Usaha Tidak Sehat (Lembaran Negara Republik Indonesia Tahun 1999 Nomor 33, Tambahan Lembaran Negara Republik Indonesia Nomor 3817).

Sinamo, N. (2009). Metode penelitian hukum. Jakarta: PT Bumi Intitama Sejahtera. 
Yosefa, D. (2010). Efisiensi dan pelaksanaan hukum persaingan usaha. Jurnal Persaingan Usaha (edisi ke-3), 115. 